\title{
The Enemy Within the Enemy Within The Canadian Army and Internment Operations during the Second World War
}

\section{Paul Jackson}

Hitler, Mussolini and the Holocaust have been powerful symbols in Western society. It is not surprising that advocates of various causes have politicised their victimisation under National Socialism. On the other side of the ledger, to have supported the Nazis in power has been a considerable burden to carry. As a result, historical accuracy has often been seconded to discursive needs. In the 1980 s, the gay movement shrewdly appropriated the pink triangle that had once identified homosexuals in Nazi concentration camps, turned it on its head, and used it to campaign for AIDS funding and social justice. In the popular press, gay activists have claimed that the Nazi crusade against homosexuals was equivalent to the Final Solution of the Jewish 'problem' in Europe. However, scholars of Nazi Germany have made clear that the Third Reich intended to eliminate homosexuality, not homosexuals - a crucial difference from its treatment of Jews. Meanwhile, as the gay movement was highlighting the victimisation of homosexual men, others have mischievously tried to paint Nazis as generically homosexual. ${ }^{1}$

In Canada, Prime Minister Brian Mulroney apologised in 1990 for the internment of Italian Canadians during the Second World War based on their 'assumed' pro-fascist pre-war activities. However, as Franca Iacovetta et al. demonstrate in Enemies Within, the Canadian state had been largely efficient in identifying and interning pro-fascist Italian Canadians when Italy joined Hitler's side in June of 1940. Their work highlights the importance of careful scholarship and the potential pernicious uses of history. By recasting the Italian Canadian community as a victim of the Canadian state's 'war on ethnicity,' activists have succeeded (perhaps naïvely) in burying a more complex history. Many Italian Canadians denounced Mussolini, fascism and imperialism in the 1930 s, thereby alienating themselves from more powerful elements in their ethnic communities. Today, in denying that there were avowed pro-fascist, proMussolini elements within the pre-war community, we simultaneously turn our backs on those who risked their social standing by denouncing injustices and oppression. Ironically, Mulroney's apology to Italian Canadians was informed by ethnic stereotyping (and perhaps political self-interest) whereas the wartime government was more cautious. If Italian Canadians can be deemed loyal by prime ministerial decree, then they can as easily be judged seditious. We owe it to our communities to probe more honestly into their actual, complex histories. $^{2}$

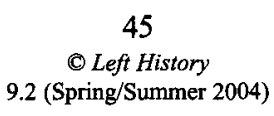


This paper addresses an intersection of homosexuality, National Socialism and internment operations in Canada. As the Second World War progressed, the Canadian Army's role as 'jailer' became increasingly important for the Allies. By 1945, the Dominion had interned approximately 40000 men, classified, according to Canadian compliance with the Geneva Convention, into three distinct groups: Jewish refugees, civilians living in Canada who were deemed suspect by the state and, by far the largest group, German combatant prisoners of war (POWs). In the very rare instances where the literature on internment operations in Canada touches upon homosexuality among internees, it is characterised as a private issue subject to the tolerance or disapproval of fellow internees. That approach reflects the medical model of homosexuality as an individual 'failing.' A much richer post-war scholarship has focused on the social and political context of homosexuality. Within that tradition, I move homosexual politics to the foreground among all three classes of POW populations. I argue that gender and sexuality were at once private, interpersonal and political issues, deeply intertwined with national, military, class and ethnic identities. Both those who imagine homosexual men as strictly victims and those who would prefer to associate them with Nazi aggressors will be disappointed with this history. What should be clear, however, is that homosexuality was of primary significance among all three groups of internees. My interest here is to explore, as far as the primary and secondary sources will allow, the range of responses to the phenomenon of homosexuality in this specific historical moment. ${ }^{3}$

In preparing this paper, I consulted a range of documents and generated oral histories. Since documentary evidence is often unavailable, many historians of homosexuality have turned to oral history for primary material. However, in this case, the most explicit discussion of homosexual relations comes from contemporary RCMP and military intelligence interrogations of POWs, martial and civilian court records, and various Army files. I supplemented those sources by interviews with fourteen former German POWs, three Canadian guards, the wartime director of naval intelligence, and a Jewish refugee, none of whom openly identified as gay. All helped me to understand 'the' POW experience. I explicitly asked each interviewee about homosexuality among POWs. Most discussed it in general terms, but denied any knowledge of sexual relations among their compatriots during their POW years. Some denounced homosexuality on moral or medical grounds and refused to discuss it further. A few suggested (sometimes quite detailed) ways that other POWs might have engaged in discreet sexual liaisons without the knowledge of their comrades. And although a couple of the interviewees had been named in wartime intelligence files as having been involved in homosexual relations more than half a century earlier, none admitted to ever having had any such experience. Only one interviewee, a German-speaking Canadian who had been 
an Army intelligence officer at POW camps during the war, himself raised the issue of homosexuality in the course of the interview. That the only voluntary discussion of homosexuality among Germans came from a Canadian observer is consistent with the history presented in the following pages.

In their late seventies and eighties, the interviewees' discomfort in discussing homosexuality reflected their formative years in Germany and Canada. But unlike most elderly Canadians who remember little public mention of homosexuality in the pre-war and war years, the ex-POWs recalled that "homosexuality was "out"' (in both senses) in Nazi Germany. Some recalled the Röhm putsch of 1934 and others the general Nazi disapprobation of homosexuality. German historiography has made substantial progress towards situating homosexuality within the Third Reich. Until 1934, the Nazi relationship to homosexuality was somewhat ambiguous. While the party had taken an official stand against it as early as 1927, the homosexuality of the party's second-incommand, Ernst Röhm, was publicly known since at least the early 1930s. Before the Nazis assumed power, Röhm's Sturmabteilung (SA) identified itself against bourgeois values. The homosexuality of Röhm and many others in the SA was part of their broader, and violent, counter-cultural politics. Although he had been aware of Röhm's sexual life for years, Hitler justified his murder with his homosexuality. In place of the counter-cultural SA, the SS rose to prominence under the direction of Himmler and the Nazis who, now in power, sought to assert their respectability. In 1941, Himmler's increasingly virulent campaign against male homosexuals culminated in the imposition of capital punishment for homosexuality within the SS and police forces. However, the difficulty in diagnosing a 'true' homosexual from those who were acting outside their normal instincts meant that the death penalty was bestowed erratically within those police services. Other male German homosexuals continued to be subject to Paragraph 175, which came into law in 1871 and outlawed oral and anal intercourse. In 1935 it was strengthened to include any sexual activity between men. Although it did not carry the death penalty, Himmler required that those found guilty of offences under Paragraph 175 be sent to concentration camps after serving their prison terms. Most perished there. ${ }^{4}$

Since the nineteenth century, there had been considerable debate in Germany regarding the causes and social impact of homosexuality. However, the Nazi regime suppressed all neutral or favourable discourses. While the Nazis themselves could not agree on the causes or dangers of male homosexuality, no one was able to argue that it was inconsequential. Historians highlight two recurrent themes: male homosexuals were imagined to be seducers of youth who, once corrupted, were then lost as progenitors of the German race. They were also frequently constructed as enemies of the state as a result of their presumed tendency to form secret cabals for the purpose of overthrowing governments. Both of those arguments were effectively mobilised against the 
Nazis' enemies. For instance, they allowed Hitler to justify the execution of Röhm and his followers in the SA. Hitler claimed that Röhm had been planning a coup. After Röhm's murder, Hitler declared that now every German mother could feel safe in sending her son to the SA. But pulling the roots of homoeroticism out of German culture was not easy for the Nazis, whose politics were based on the männerbund, or male camaraderie. As historian George Mosse and others have documented, German intellectuals had identified "homoeroticism as the crucial element in male-centred organisations and institutions." 5 The Nazis had to reconcile their highly gendered political, social and military order, based upon the prominence of comradely bonds between men, with frequent anti-homosexual campaigns against their enemies. The need to distance themselves from what they feared they were may have been at the core of the Nazis' (and especially the SS's) great discomfort with homosexuality. This process, which has since been labelled 'homophobia,' was certainly not unique to German men, but may have been accentuated as a result of the more explicit discussion of homosexuality and homoeroticism in German pre-war culture. ${ }^{6}$

The Canadian Army was responsible for maintaining order among all of the prisoner populations. According to the Geneva Convention in force at the time, German POWs were subject to the same military law as Canadian servicemen. Canadians accused of homosexual acts were subject to court-martial proceedings. Those found guilty faced punishments that varied according to their rank, service and importance to the war effort. All officers convicted of homosexual offences were dismissed from His Majesty's Service. Soldiers, sailors and airmen were more likely to serve prison terms that varied in length in direct proportion to their proximity to the front lines: the closer to the fighting, the shorter the sentence. However, in contrast to its practices relating to queer Canadian servicemen, the military chose to protect homosexual Germans from their comrades' assaults. Using various techniques, from intelligence officers to courts martial to the criminal justice system, the Canadian Army and state prosecuted those German soldiers and internees who attacked comrades on the basis of their homosexual orientation or behaviour. Perhaps because it was able to distance itself from the imputation of condoning immoral behaviour in its own ranks, the Canadian military acted on the principle that the persecution of German homosexual soldiers was a greater threat to military discipline than was the expression of homosexuality itself. Since, during the war and until the 1990s, the Canadian Forces justified the exclusion of homosexual men and women from the military on the basis of their threat to unit cohesion, it is significant that they seem not to have accepted that rhetoric when they were actually responsible for good order among POWs. Also, in light of the construction of homosexuals as risks to national security in Canada during the Cold War era, it is significant to note that there is no record in all of the 
copious material upon which this paper is based that the Canadian Army and intelligence services ever tried to blackmail homosexual German prisoners. In fact, they employed tactics that would have been equally available in the case of heterosexual targets. ${ }^{7}$

The first category of 'POW,' refugees, arrived in Canada via England. Britain had accepted Jewish refugees from Nazi-dominated Europe before the outbreak of war. When the fall of France in June of 1940 increased the prospects of a Nazi invasion of England, Churchill's government feared that it may have unwittingly admitted fifth columnists among the refugees. Consequently, it transferred 2290 to Canada. Interned in refugee camps in eastern Canada, almost all had been released by December of $1942 .{ }^{8}$

The second category was comprised of those thought to pose a threat to Canadian security but who were non-combatants. Communists and German and Italian Canadians who had actively supported Hitler and Mussolini were arrested and interned at the discretion of the Department of Justice. Included in this category were Canadian fascists and opponents of government policy, such as Montreal Mayor Camilien Houde. Enemy merchant seamen captured by the Royal Canadian Navy (RCN) were also designated Class Two prisoners. Since this category represented such a wide array of internees, they will be identified in the following discussion as Class Two prisoners. ${ }^{9}$

Class Three designated combatant prisoners: German officers, soldiers, sailors and airmen. These came from Britain in three waves and numbered approximately 35000 at their peak in late 1944 . The first group began to arrive after the fall of France in 1940, when Britain feared that POWs held in the United Kingdom could be released by invading forces. They included sailors as well as soldiers and officers captured on the continent before the Allied retreat at Dunkirk and pilots shot down during the Battle of Britain. The second group came to Canada in 1942 and 1943, captured from Rommel's army in North Africa. Finally, Normandy prisoners arrived throughout the second half of 1944. Although they remained British prisoners, under the Geneva Convention Canada had full authority as the Detaining Power. Combatant prisoners were held together in various camps and labour projects throughout the country. ${ }^{10}$

All of the POWs lived in same-sex environments, in some cases for as long as six years. Combatant prisoners were separated according to rank, an arrangement that roughly separated them according to class and age. The largest two camps, Lethbridge and Medicine Hat, housed only other ranks. In camps shared by officers and ranks, the former enjoyed special privileges and more private accommodations. While Germans were the dominant presence among the combatant prisoners, there were substantial numbers of Austrians, as well as Czechs, Poles and Romanians who had been impressed into service by the Nazis. The combatant German POWs were divided ideologically: many 
were communists, socialists and liberals who, while often proudly German, did not support Hitler and National Socialism. Likewise, the Class Two prisoners contained an array of attitudes towards Canada, Germany, fascism and the war. Jewish refugees and Class Two prisoners included a wider age of internees, from adolescents to elderly men. The Jewish refugees were the most ethnically homogeneous.

The commanding officer of each district (DOC) was responsible to the Director of Prisoners of War (DPOW), Lieutenant Colonel (later Colonel) Streight, for the camps within his jurisdiction. The daily operation of each camp was in the hands of a commandant who oversaw camp administration. The Veterans' Guard of Canada assumed responsibility for guard duties and filled many administrative positions. Under Canadian regulations, prisoners chose a spokesman to represent them in discussions with Canadian military authorities. If he felt that the prisoners' grievances were not being addressed by the Canadians, he could complain to the Protecting Power, Switzerland, through its Consul General in Ottawa. (Argentina was the Protecting Power for the Italians.) Spokesmen were responsible to the Canadians for maintaining order among the prisoners. In large camps, there were also section leaders and hut leaders to oversee discipline. Another political organisation existed in many Class Two and Three camps, headed by ranking Nazi Party officials, which dealt with education, entertainment, recreation and policing. Some of the sections operated openly, but the policing function, or 'secret service,' was contrary to the Geneva Convention and thus hidden from the Canadians. Since POWs were subject to the military laws, orders and regulations of Canada, German prisoners should have turned over those who had broken Canadian laws to Canadian authorities for punishment. However, such a system was unworkable in the context of wartime national rivalries. Instead, POWs policed themselves and administered their own punishments in violation of international, but consistent with German, law. Military courts were held in which witnesses were called and transcripts prepared for use in post-war Germany. ${ }^{11}$

The significance of homosexual activity varied greatly according to the type of camp, its size and social and political organisation. Erich Koch, who spent years in Jewish refugee camps in Ontario and Quebec, witnessed the pervasiveness of homosexuality among his comrades:

The only way in which we could have heterosexual love affairs was in our fantasies. But no fantasy at all was required to have affairs with men: we were surrounded by potential male love-objects who were all too real. Father Anton Ummenhofer in Farnham wrote in his diary - no doubt with a shudder - that as many as 50 percent of the camp had succumbed to homosexual love. 
Koch's casual description of the prevalence of homosexual romances in the refugee camps suggests that some men did not see them as socially threatening. However, while homosexuality was a common response to the need for love and sex, it was not normalised. Koch remembers one refugee, "a one-man morality squad, making the rounds at night and shining a flashlight into the faces of men and boys whom he found in bed together." The concern over homosexuality in the refugee camps also provoked a formal response: "On one occasion they held a much publicised trial that ended in the condemnation of two boys. As punishment they were ordered to fight each other "until there was a bloody mess." [emphasis added] The sentence of the court suggests that the Jewish refugees who assumed authority imagined that physical aggression could, and should, replace physical affection between men. The result is a stark example of how gender norms are actively constructed and reproduced. While sexual relations can also be violent, Koch suggests that it was sexual affection between males that was disturbing to the Jewish leaders. ${ }^{12}$

There were two sources of physical force in POW camps. The Canadian Army posted troops to protect the public from the POWs and to ensure order in the enclosure. These troops were a shadowy presence for the POWs, visible in the watch towers which marked the perimeters of the camps and, rarely, called upon to quell disturbances. Meanwhile, the prisoner administrations often maintained unofficial police forces, armed with sticks and fists, to back up their own authority within the camps. All POWs were aware of these two signposts of political authority. Whether Class Two and Three prisoners chose to recognise the Canadian or German state could depend upon which would serve them better. The former was validated by international law, the latter by Nazi decree. Queer POWs, even if they were a substantial presence as the years passed, were politically atomised. They sometimes defended themselves individually against police aggression, but it is unlikely that queer POWs saw even the possibility of politically legitimising their sexual difference. Those who accepted their homosexual desires knew very well that society did not. Meanwhile, those who sought political power within the POW world consistently used the disgust of homosexuality and fear of being named homosexual to consolidate their authority. All players had to anchor their arguments in public discourses which were overwhelmingly anti-homosexual. ${ }^{13}$

The following section will analyse the evolution of the anti-homosexual campaign throughout 1942 and 1943 in the Class Two camp named Ripples, outside of Fredericton, New Brunswick. The Canadian Army, the Camp Commandant, the Camp Spokesman and the administration were all complicit in an attempt to rid Ripples of what they saw as the immoral and degrading vice of homosexuality. However, the attempt to achieve heterosexual purity led to intense rivalries based on class and national allegiances. The prisoners and the 
Canadian Army generated a great deal of evidence regarding the homosexual culture and the attempts to eradicate it. Consequently, Ripples offers a more detailed discussion of sexual politics than most camps. In Class Three camps, a different politic developed. The final section will consider the dilemma faced by combatant prisoners marked as queer by their POW administrations. By its response to the crises that developed in these various camps, the Canadian Army settled on a practical approach to homosexuality, which starkly contradicted the policies and procedures it upheld in relation to Canadian soldiers and officers. ${ }^{14}$

\section{Ripples in the body politic}

In the summer of 1941, 213 seamen and officers from three captured German merchant ships were interned at Ripples. One year later, they were joined by approximately 400 civilian internees: German-Canadian, Italian-Canadian, English and French Canadian fascists and opponents of government policy, all of whom were deemed potentially dangerous to the Canadian war effort. No language, class, age, nationality, ethnicity, politics or sexual orientation could bind the various prisoners assembled there. As with the other classes of wartime POWs, the inmates of Ripples were emphatic in their insistence that, while imprisoned, they were not criminals. Most declared themselves respectable men, unjustly incarcerated as a result of international politics beyond their control. Tensions arose in the enclosure soon after the arrival of the civilian internees. German-Canadians, who typically argued that their imprisonment was unjustified since they were loyal to Canada, were unpopular with some merchant seamen, who saw themselves as loyal Germans under enemy control. Moreover, many merchant seamen resented the influx of civilian internees that strained the camp's limited resources. ${ }^{15}$

In January 1943, Captain Aschoff, the senior officer from one of the merchant ships, urged the Camp Commandant, Lieutenant Colonel Bedson, to transfer the seamen to a separate camp. He argued that "honest, hard-working German seamen" were being forced to share the enclosure with "undesirable elements ... who by rights should be in jail." The transfer was imperative since "the moral [sic] of the younger men is being more and more endangered, and because some deplorable cases have already happened." The "deplorable cases" referred to homosexual relations between merchant seamen and civilian internees. He asked that the 213 seamen be "placed in separate huts until the transfer can be effected." His own research demonstrated that the merchant seamen in the camp were composed of 146 Germans, 39 Italians and 28 men of various other nationalities. Captain Aschoff, however, insisted that the main category for separation should be between the seamen and all others. Only the seamen had been interned because of their occupation. Others, especially the 
German-Canadians, had been interned because they were potentially disloyal. Aschoff argued that the youngest seamen were especially vulnerable to the vices of the older German-Canadians. Underlying his argument was the fact that he had lost much control over the merchant seamen. Before the transfer of the civilian internees to Ripples, the ships' officers had been the only source of authority within the enclosure. ${ }^{16}$

One month earlier, a camp committee had been formed to root out the homosexual relations that were believed to be furtively corrupting Ripples' society. The Investigation Committee into Homosexual Practices was composed of the second officers of the three merchant ships: Werner, Kubacky and Rademacher. According to the Camp Spokesman, from 11 December 1942 until 16 January 1943, they "heard witnesses, received evidence from some of the persons involved and investigated, in a most thorough manner, every rumour, denunciation and information received." The Committee had been nominally appointed by the Camp Spokesman, a German-Canadian internee named Brendel, with the approval of the Canadian Camp Commandant, to find and punish internees guilty of homosexual offences. However, that the three members were all German merchant seamen suggests that it was an attempt by that group to expand ship discipline to the camp in general. Nevertheless, the Committee received support from a wide cross section of the camp population. On the other hand, it may be more accurate to assume that few were willing to challenge it. ${ }^{17}$

The Committee quickly assumed great power. In soliciting the help of internees to pursue its goal of 'moral purity,' it turned the camp upon itself. Increasingly, the Committee pressed prisoners into demonstrating their own virtue by denouncing their queer neighbours. However, many remained neutral and regretted the effect that the proceedings were having on camp society. The Committee's methods and unlimited power meant a reign a terror for those who had kept their sexual relations reasonably hidden. Some were called to account for their previous lack of discretion. The Committee interrogated Helmut, a civilian internee nicknamed Susie, for more than three hours. He reported that "During all that time I was menaced with concentration camps, long sentences of detention, emasculation and Lord knows what. Enough to drive anybody crazy." Kurt (a civilian internee) and Irwin (a 23 year old German national who had lived in Canada since the age of five) both admitted before the Committee that they had had sexual relations with him. Although he had admitted to the sexual affairs during his interrogation, 'Susie' later wrote to the Committee that he "never, at any time, had anything to do with Irwin, and that due to the painfulness of the situation during the cross-examination I was in such an emotional uproar that I would have confessed murder, had they asked me to do so." 18

Carl, a 21 year old merchant seaman, was accused by the Committee of 
having an affair with another young seaman named Hans. The Committee told him that, if he confessed, the charges would be dropped. Otherwise "steps would be taken after returning to Germany." He denied the charges. The Committee had him watched by another seaman who soon reported that, peering through the window to the ablution room, he had seen Carl and Hans make love. The following day, Werner called the two to the same shower room when the other prisoners were at lunch. He confronted them with the new evidence. When they denied it, a gang of internees, including four seamen from Carl's ship, descended on them with belts, ropes and sticks. The attackers tore their trousers off and beat them severely. Carl and Hans later appealed to Spokesman Brendel for protection. He said he could do nothing to help and refused to move them out of the seamen's hut in which they now felt in constant danger. ${ }^{19}$

When Gerhard Von $M$, the sports representative, was called before the Committee, he chose to fight back. He enlisted the help of J. C. Farr, an Englishman and the former president of the Ontario Fascist Party. Farr advised Gerhard to challenge the validity of the court on nationalist grounds. In a letter to Spokesman Brendel, Gerhard objected as a German-Canadian to being tried before three German nationals on "charges of a very serious nature laid by other internees against me personally." He asserted that "these hideous and slanderous charges aimed against my honour and good character are without the slightest foundation." He refused to defend himself except against competent authorities, properly constituted; only the Canadian state had the power to prosecute "such serious charges." Meanwhile, he offered his resignation as sports leader of the camp, his work being hampered by the "rumours and insinuations ... going on day and night against me within the compound". Although he appeared before the Committee, Gerhard was far from co-operative and refused to respond to the witnesses who had testified against him. Brendel wrote to Gerhard, saying that he, "especially as sports [sic] representative should be more than interested to straighten out this affair, as in your hands were the physical well-being and the spiritual health direct or indirect of the internees." He asserted that the authority of the Council came "by order of the Commandant" and therefore it had "the right to investigate anything necessary in the interests of the camp." 20

A civilian internee named Baumgarten was equally contemptuous of the Committee, although it cost him severe beatings. Baumgarten was open about his homosexuality, and so gathering evidence against him should have been relatively simple. Rademacher was the Committee member detailed to investigate the rumours. He discovered that

Baumgarten offered this boy 50 cents to commit buggery with him. I couldn't get any definite information so I decided to go to Baumgarten and confront him with this informa- 
tion. Baumgarten did not deny this allegation and he did not confirm it. He did say 'Baumgarten isn't that cheap, I always offer a dollar.' He said, 'If you get too close to me I will cut your throats['] (Meaning the Investigating Committee). [sic]

Baumgarten refused to co-operate and was unique in the camp in that he also refused to deny his homosexual activities. His defiance alienated both the investigators and those who attempted to defend themselves on the moral high ground by denying the charges. ${ }^{21}$

Although some prisoners defied the legitimacy of the investigating committee, it used various methods to ensure co-operation. First, it exploited the fear of being labelled homosexual. Second, the actual information-gathering tactics unsettled many victims, setting prisoners against each other and discouraging solidarity. It turned lovers into potential enemies whose testimony could have devastating effects. That some could escape punishment by testifying against others meant that none were secure. Third, to be ostracised as queer within the camp could be a disturbing prospect for many POWs. Fourth, the constant threat of being physically attacked terrified many prisoners. The prisoners referred to the experience of being beaten in the night by unknown assailants as "holyghosting." 22

The impetus for the investigation and punishment of homosexual offences came entirely from within the enclosure. The POW leadership at Ripples was unique in discussing the camp's homosexual subculture with the Canadian authorities. Neither the Jewish refugees nor the German combatant prisoners were willing to expose their dirty laundry to Canadian eyes. At Ripples, however, internal rivalries in the Class Two population paved the way for Canadian involvement. When the Commandant had approved the establishment of the Committee into Homosexual Practices, he was aware that there had been cases of violence against queer prisoners. He therefore sanctioned this more rational, although illegal, attempt at self-government. In fact, the Canadians engaged the POWs' Committee to investigate their own personnel. The Committee informed Staff Sergeant Nesbitt that it suspected that one of the Canadian scouts, Corporal T, was involved in the camp's homosexual underground. Scouts were unarmed Canadian Non-Commissioned Officers (NCOs) who monitored conditions within the enclosure. Nesbitt asked to be kept informed of the Committee's investigation of Corporal T. In this way, the disdain for homosexuality united the Canadian camp authorities and certain representatives of the POWs.

When the Investigating Committee had concluded its work, it presented its findings, "far the saddest chapter in this camp," to a special session of the prisoners' Camp Council. The members of the Council unanimously decided to use "all ways and means at [their] disposal ... to deal with those fully responsible 
for the practices and to see to it that these unnatural and distasteful occurrences" be made impossible in the future. The names of the seven guiltiest internees, the "seducers," were read out publicly after roll call on 31 January with the warning that "suitable measures" would be taken against them. All of the men named were German-Canadians. Also read out by the leader in each hut was a detailed account of the findings of the Committee and the orders that the Council was issuing in response. That German-Canadians were targeted is not surprising, given that the German merchant seamen controlled the Committee. German-Canadians consistently argued that their internment was unjust since they were loyal to Canada, a position which insulted the nationalism of the German merchant seamen who saw their ex-patriots as traitors to Germany. ${ }^{23}$

The guilty were divided into six categories. There were those who had come to the camp as "homosexualists", those "that with the lack of self-control [had] taken up this practice for lack of intercourse with the opposite sex" and "immature youths" who had been victimised by both of those groups. The identities of the immature youths were withheld in order to give them a chance to redeem themselves "to a flawless and decent way of living" under the guidance of responsible comrades. The fourth category consisted of those under suspicion without proof of guilt. A separate category was created for those who had not co-operated with the Committee, but had helped the accused. To have demonstrated solidarity with the accused was regarded as morally suspect. The Canadian scout, Corporal $\mathrm{T}$, had earned a category unto himself for distributing indecent pictures and literature to internees, thus abetting "unnatural inclinations". ${ }^{24}$

In order to thwart homosexual relations in the future, all internees were enlisted to patrol the camp in search of infractions. While washrooms, boiler rooms and the recreation hall were to be watched most closely, any single room required attention. Witnesses were obliged to report the names of offenders to the hut leaders, along with details of the offence. To withhold knowledge of homosexual relations was made a punishable offence. While the cases that had been uncovered by the investigation were to be disciplined within the enclosure, future cases would be handed over to the Canadian military authorities. The prisoners were reminded of the heavy penalties under section 175 of the German criminal code. However, it was acknowledged that, as POWs, Canadian laws applied. The relevant sections of the Canadian code were listed: life imprisonment for buggery (section 202), ten years for attempted buggery (section 203) and ten years and whipping for indecent assault upon a male (section 293). It was advised that should anyone be caught with indecent literature still in circulation "it [would] be held against him." It was "forbidden to lay and sleep together in one bed" and to "completely cover the bed with blankets or cardboard; the beds can only be covered on one side, so that a full view of the 
bed can be had." The unanimity of the Camp Council in this attempt to "lead the camp back at once to moral cleanliness" was stressed. As for Corporal T, who stood outside of its authority, the camp was assured that the Council had asked the Commandant to remove him from provost duties inside the enclosure.

As well as having their names read in public, the seven convicted men were banned for three months from movies, canteens, entertainment and sporting activities. In response, Irwin simply announced his intention to defy the sentence. The unwillingness of some of the men implicated in the scandal to accept their sentences called the authority of the Camp Council into question. In the face of this defiance, it tried to force compliance with its judgements through a rash of nocturnal holyghostings on the recalcitrant POWs.

The accused had to find an authority that could challenge the Council. That, of course, was the Canadian state. Gerhard Von M charged the Camp Council with defamation of character under the Canadian criminal code, and sent a copy to the Commandant. In letters to the Commissioner of Internment Operations (the forerunner to the Director of POW), the Camp Commandant and the Secretary of National Defence, several of the accused insisted that Canadian military authorities institute formal trials for their alleged homosexual offences. Since Irwin's name did not appear on the list of homosexual 'seducers,' he was able to deny the real offence. Although convicted of accepting 'blowjobs' from 'Susie,' he wrote to the Commissioner that "because of my pro-Canadian sentiments I ... am stigmatised as anti-Nazi and am on the 'list' for a 'gang beating' together with the group to which I belong." He wrote that, since the imposition of the sentence, "ordinary passage within the compound invites insults, threats, and is positively hazardous. ... My person here is in serious danger and I request that I be moved". Most of those whose names had not been publicly connected with homosexuality now argued that their crime had been loyalty to Canada. As German-Canadians, they were doubly served by an appeal to patriotism: it undermined the charges of immorality and positioned them favourably in the eyes of the state. Thus, their future requests for release to the Department of Justice could be supported by evidence of loyalty to Canada. ${ }^{25}$

Gerhard Von M's threat to charge the Committee with slander in civil court also meant that the existence of that illegal body would be brought to the attention of both Canadian and German authorities. The military's abrogation of its responsibilities for maintaining order would have been discussed in open civil court along with whatever findings the Committee chose to reveal. While the Committee had been formed to keep order in the camp, the Commandant now saw that it was having the opposite effect. The refusal of the alleged homosexuals to recognise the judgements of an illegal court had cornered the military. As the crisis deepened, the Commandant advised his DOC and Colonel 
Streight, the Director of POWs, of the situation. Several unarmed guards were posted in the compound to protect the targeted prisoners, but this had no deterrent effect on the aggressors. ${ }^{26}$

On the morning of 6 February 1943, the ex-Committee members organised a purge of the accused homosexuals. Groups of approximately ten men converged on each of the twenty-four most flagrant homosexual offenders who were ordered to pack their belongings and were 'escorted' to the main gates of the camp. In each case, the targeted men were beaten while they were packing. Then, a gauntlet was set up outside their huts to beat them as they tried to make their way to the gate. At the main entrance, although the homosexual internees were being beaten in front of them, the guards were unable to open the gate since the entire camp population was massed on the other side. The victims were led to the camp hospital, located inside the enclosure, by the Canadian guards who had been posted inside the compound. Meanwhile armed troops were called in to restore order since the leaders of the riot defied the guards.

In the re-organisation of the camp in the wake of the riot, the prisoners who had been targeted as homosexual were given a separate, protected section of the camp. The Canadian military, which had hitherto avoided any direct involvement in camp politics and the morality of internees, was forced by the riot into an active role. While holyghostings and other abuses of the Committee were illegal, they had been invisible to the outside world and therefore sanctioned by the Commandant as the most convenient way to keep order. However, the fact that troops had to be sent into an internment camp to quell a riot could not be hidden. The 'peace' that had resulted from the Commandant's forbearance of the Committee into Homosexual Practices ended in violence and a dangerously polarised prison population. The Canadian military was now forced to confront the reality of homosexuality more explicitly.

Lieutenant Colonel Logan, the Officer Commanding Military District Seven, called one court of enquiry into the riot and another into camp conditions and administration. Witnesses who had been interrogated by the Committee were granted immunity from prosecution for homosexual offences. The legal advisor for the District took their summaries of evidence along with that of Canadian camp personnel, members of the Committee and other POWs. The court found that the riot had been caused by three factors: the presence of too many nationalities in the camp, the attempt by a Nazi element to dominate camp politics and the abuse by the Camp Council of its power. Logan qualified the finding in his confirmation, stipulating that any camp council would be illegal and therefore its power could not be at issue. There was no mention of homosexuality in the court findings. Although the second court had a broader mandate, it too found that the cause of the disciplinary problem was the existence of too many nationalities.

Why would the courts have ignored the issue of homosexuality in their 
findings and recommendations and focused on nationality? It is true that the Committee's investigations into homosexuality were informed by nationalist considerations. Queer POWs were selectively targeted and punished according to their age, class and national allegiance. In return, Canadian nationalism gave the accused a solid footing to defend themselves. But in framing the reports, details concerning homosexuality in the camp remained buried. In the House of Commons, opposition parliamentarians asked the Minister of DND for an account of the riot. The Deputy Minister, citing the findings but avoiding the details of sexual politics contained in the bodies of the courts of enquiry, was able to frame an answer that focused on the mix of nationalities and only vaguely referred to an undefined moral issue. The findings allowed the military and political authorities to avoid public mention of the embarrassing issue of homosexuality and to hide the Army's complicity in the Committee into Homosexual Practices. At Ripples, a shared gendered and ethical perspective united both sides of the wire. Nowhere was this more evident than in the willingness of the Canadians to rely upon the POWs' Committee to investigate Corporal T's sexuality. Predictably, the Canadian courts of enquiry exonerated him, just as the Committee had managed to hide the evidence of its own merchant seamen from public view. The reluctance of the Canadian authorities to highlight the depravity of their enemies was not solely a function of their own embarrassing complicity in the investigations. Since the Dieppe prisoners were being held in Germany, it is possible that they were sensitive to the possibility of a German response which may have similarly slandered Canadian soldiers. More importantly, naming one's enemy queer was itself an unmanly and unseemly act.

Court-martial proceedings were instituted against some of the aggressors in order to regain control of the enclosure after the riot. Evidence gathered from the victims and guards was sufficient to convict ten prisoners, both enemy merchant seamen and civilian internees, under Section 40 of the Army Act identifying these acts as "conduct to the prejudice of good order and discipline among prisoners of war" by participating in a disorderly assembly. All were convicted and sentenced to terms of imprisonment ranging from one to nine months. The trials were very long and detailed by wartime military standards. The Military District legal officer, Captain Hanson, prosecuted the offenders. They were defended by Montreal lawyer Salluste Lavery, an outspoken critic of the unjust internment of Canadian citizens under the Defence of Canada Regulations. In all cases, his defence was based on the argument that the aggressors had been provoked by the immoral actions of the 'sexual perverts' and the neglect of the Canadian authorities. In response, the prosecutor favoured the view that the victims' political opposition to Nazism motivated the attacks. This was a more attractive position for the Army, which otherwise had cornered itself into championing the rights of homosexuals to live free of 
persecution. Since witnesses were given immunity from prosecution, the defence was effective in proving that the accused had attacked the victims on the basis of their homosexual behaviour. ${ }^{27}$

Lavery's argument positioned the aggressors as motivated by both rational and passionate responses to an immoral situation. Injustices had been piled upon the civilian internees, beginning with their internment in 1939:

Here in this camp are men which were torn away from their wives and kids, men who are in this country for thirty years and more, men who developed this country, cultivated the land, have model farms ... honest, lawabiding and taxpaying citizens and guests of this country. I must say that there never was any more injustice in this country as it was in 1939 when these men were arrested and put behind the wire - for what?

In that way, the homosexual offenders disappeared from the ranks of civilian internees who had earned the right to citizenship through their labour. However, they reappeared in the camps as a threat to decency:

The Prisoner's Council knew that Canadian authorities would never have sent prisoners suffering from physical leprosy among sane men, but they were appalled at seeing that the presence of prisoners incurably affected with moral leprosy was imposed upon honest and sane young men.

Lavery appealed to the manly virtue of the officers of the court by asking them to identify with the righteous internees:

... those men, in the given circumstances, not only had the rights and privileges to act as they did, and the protection of natural and divine laws behind them, but I also declare that it was their duty, a most sacred duty, to do as they did; and if they had neglected or refused to do so, they would be worthy only of contempt and scorn, they would not deserve to be called men and they would have betrayed the trust that youth has a right to find in elder and responsible people.

The notion that it was the duty of decent men to stop homosexual offenders, a recurrent theme throughout the wartime records, was deeply based in gender identity. Each man was responsible for upholding the dignity and honour of the male 'race.' Typically, protection of the innocent was proffered as the justification for the attacks. In cultural terms, adult males were responsible for the 
reproduction of the next generation of men. Lavery appealed to the officers as fathers:

Take for instance one of you gentlemen has a boy with the age of twelve or fourteen years and you have one of these homosexual beasts as your neighbour without knowing it, the first thing of one of these beasts is to lure him into his net, frighten him into submission and then use him at his will. What would you do whenever you find out? Give him credit for his abnormal deeds which are lower as those from a dog at the street? [sic]

This tactic was reinforced by Lavery's argument that the Canadian authorities had not protected the upright prisoners against sexual perverts. In defending the youngest accused, he shamed the authorities for their inaction:

... this young man [who joined in attacks on homosexual prisoners] made no attempt at, nor had he any intentions of usurping the functions of society, but only acted in selfpreservation lest society could not arrive in time to save him.

Just as chivalrous men were the protectors of women's virtue, they needed to protect their own against the threat of sexual aggression by other men.

As a civilian lawyer, Lavery was not constrained by a desire to appease his military superiors. He accused the military of having abrogated its responsibility:

The Camp commandant refused to deal with the matter and he suggested that the internees settle it among themselves in the best way possible. So the camp responsible people had to face a dilemma; let things go and corruption spread with impunity, or try to stop it in some way without disturbing the good order and discipline of the camp.

While Lavery based his arguments on the rights of internees to be protected from 'sexual perverts,' he had clearly outlined the reality of camp life. After reviewing the proceedings, the Judge Advocate General (JAG) forwarded the files to the Adjutant-General (A-G), responsible for internment operations, "in view of the unusual nature thereof and the statements made therein." He suggested that the A-G may "require the matter brought to the attention of the appropriate persons." However, the Director of POWs, Colonel Streight, responded that "it is not the detaining power [Canada] which is on trial but the 


\section{Jackson}

accused." He noted that the POWs could come forward at any time with evidence "of certain criminal practices" and that charges would "be profered [sic] immediately," ignoring the fact that the Commandant had authorised the prisoners to deal with the issue themselves. While Streight's rejoinder may have absolved his Directorate of responsibility for the criminal homosexual activity and ensuing tensions in the POW camps, it did nothing to advance good order and discipline within the enclosures. ${ }^{28}$

The courts of enquiry and the courts martial tried to separate the issues of homosexuality and military discipline and focus solely on the latter. Looking beyond the recommendations, and in step with the JAG's suggestion, Colonel Streight handed the problem of homosexuality over to the RCMP. Commissioner O'Brien sent Sergeant Lyons to Ripples to report on the prospect of charging POWs for homosexual offences under the criminal code. After interviewing some of the men who had been involved in the various investigations, he reported that

It can be appreciated that offences of this nature are usually committed in secret, and very seldom would the offence be witnessed. There is no doubt that these offences were committed in camps of this nature in the past, and there seems little hope of suppressing them altogether in the future. ... further investigation hopeless. It is quite significant that the internees who might be in a position to give evidence are under constant duress and while some of them might give certain evidence at a court of enquiry, under protection of that court, they would not give evidence in a civil court.

Sergeant Lyons' assessment demonstrates the real difficulties that faced the DPOW, not to mention historians. But it would be a mistake to infer from the secrecy that shrouded homosexual relations that they were not socially and politically significant. Certain conditions, such as those that obtained at Ripples, periodically exposed the fundamental importance of sexual identity in male society. ${ }^{29}$

If the courts of enquiry had honestly pursued their mandate to study the circumstances surrounding the riot, they may have been able to frame the real difficulties that the Directorate of POW would face as internment operations expanded. Buried in the courts of enquiry and subsequent courts martial was a wealth of information regarding the sexual culture and politics of camp society. They revealed a significant incidence of homosexual love among all social groups, notwithstanding strong ideological opposition to it. The courts showed that some men satisfied physical and emotional needs at great risk to their own welfare and thereby placed themselves in opposition to Canadian civil and mil- 
itary laws and aroused passions among fellow prisoners. By the terms of the Geneva Convention, police functions of the Canadian state were not allowed into the enclosure to detect homosexuals. However, the courts showed that prisoners were able to uncover some of the incidents and then usurp disciplinary powers to punish the guilty outside of Canadian laws. Had the Army taken note of the evidence it had accumulated, it would then have been challenged to find ways to deal with a problem inherent to single-sex POW camps where homosexuality is outlawed. The problem would resurface in the combatant prisoner population with even more serious consequences.

\section{Combatant prisoners}

The combatant POWs developed social and political organisations similar to those of the Class Two prisoners. The big camps with populations of thousands of inmates were largely self-contained societies. The Canadian military authorities had little understanding of the political and policing functions that governed the men inside the enclosures. Primarily, they viewed the prisoners as a source of knowledge regarding Nazi military secrets. Prisoners' correspondence to their relatives in Germany was mined by Canadian censors for indications of enemy morale. Letters that passed between POWs were intercepted and studied for hints about prison culture and the Army's new counter-intelligence department used every opportunity to gather information that might help the Allied cause. All combatant prisoners had something to offer their Canadian 'jailers.' POW culture evolved with the knowledge that it was vulnerable to betrayal. Consequently, loyalty to Germany became the central creed of prisoner society. The POW leadership defined its goal as maintaining morale and keeping the men fit for the time when they could again serve the fatherland. The policing function operated covertly and reported to the Nazi leaders in camp. Known as the 'secret service,' it was composed primarily of prisoners who had belonged to a police force in Germany, often the Nazi SS. The ranking Nazi Party members were often the eminences gris behind the official camp spokesmen who represented the prisoners to outside authorities. ${ }^{30}$

Homosexuality and disloyalty to Germany were the two most serious infractions in combatant camps and they worked in lock step. Prisoners who wanted to demonstrate their loyalty to the Nazi cause were assigned by the secret service to spy on their comrades. Some chose their own targets. The earliest prisoners to arrive in Canada, able to maintain an uncritical faith in Hitler's vision, were often the most enthusiastic spies. Under Nazi Germany, loyalty to the country was known as 'working towards the fuehrer,' which signified an unspecified commitment to the will of Hitler, whose interests were thought to be synonymous with those of the nation. Homosexual transgressors became a favourite target for the secret service. They were isolated in the camp 
social life, existing in underground networks or single intimate relationships. After years of persecution in Nazi Germany, they were clearly defined as enemies of Hitler's state. The search for homosexuals had the added advantage of reminding the POW population of the presence and power of the Nazi elite. If warranted, a trial would take place in which the accused would be confronted with the evidence against him. Legal counsel would transcribe the proceedings for use in Germany after the war. Those found guilty would be visited by several prisoners appointed by the 'Minister of Punishment' to administer beatings. ${ }^{31}$

Homosexual offenders often preferred to present themselves to the Canadian authorities as anti-Nazi. Whereas homosexuality was equally shameful in the eyes of the Canadian captors, they could expect to be treated with respect for challenging the Nazis on a political level. Furthermore, many homosexuals had good reason to become anti-Nazi. When conditions in camp were no longer tolerable or their lives were in danger, homosexual prisoners could ask the Canadian authorities for protective custody. Their POW tormentors then viewed them as traitors, not homosexuals. They were expected to accept all punishments meted out to them in the enclosure and remain loyal to the Nazi cause. For this reason, holyghostings were often called 'comradely admonitions.' One prisoner who worked with the secret service explained during the course of a court trial the purpose of beating homosexuals in camp: "If I give a comrade such an admonition, it is proof that I have not given him up altogether, but that I have still some hope for him, and by beating him up I am bringing him to his senses." As at Ripples, those convicted of homosexuality by the POW administration were sometimes excluded from camp society. However, it was important for the German administration that even shunned POWs remain in the enclosure. ${ }^{32}$

Homosexuality had already been conflated with disloyalty in German thought. Good Germans, like good Canadians, were defined as morally, sexually straight. Not only were queer Germans thought to have betrayed the nation, but those who betrayed the fatherland were also suspect on sexual grounds. At the large Medicine Hat camp in 1943, the loyalty of a group of prisoners from the North African campaign was called into question. Regiment 361 was composed of soldiers who had fought with the French Foreign Legion before the war. During the early years of the war, these men had been exempted from military service because of their questionable loyalty to Germany. However, after the fall of France, their expertise in the Middle East was exploited and they were attached to Rommel's Afrikakorps. At Medicine Hat, they socialised together. They spoke French among themselves and often congregated in a 'depression' in the flat fields behind the sports and theatre halls. Many were older, most were single, and all were adventurers who had joined the Legion for a variety of reasons during the 1920s and 30s. Their close bonds, 
their perspective which had taken them beyond Germany's borders, and their language made them suspect to many nationalist POWs. One ex-POW recently remarked that "they nearly all were homosexual and the get togethers in the grassy hollows had taken place for that reason." The camp gossip defined these extra-nationals as queer. ${ }^{33}$

In the heat of June, 1943, three ex-legionnaires were called to appear before a court called by the POW administration to enquire into their activities in the depression. One of the three, waiting to be questioned by the court, escaped his guard and made a run for the wire. A crowd of prisoners showered him with stones and epithets of "traitor" from behind the warning wire. Meanwhile, the prisoners, who were aware that the legionnaires were being investigated, became incensed at this affront to the camp's Nazi authority. They grabbed the friend of the escaped prisoner, who was waiting his turn to be interrogated, beat him to death and hanged his body in the Sports' Hall. Over the subsequent days, many ex-legionnaires decided to seek Canadian protection. RCMP and military intelligence investigations into the murder revealed that, indeed, many of the legionnaires were homosexual. On the other hand, those investigations also found that some of the police within the POW secret service were homosexual. As was the case within the Canadian military, it was not queer behaviour that made one homosexual, but the assignment of the label. The sexuality of those whose place in camp society was secure did not fall under the surveillance of the secret police. ${ }^{34}$

Not surprisingly, many prisoners felt particularly insecure in their masculine identity. Stripped of their independence, they were forced to rely upon an enemy military for their existence. Many focused on sport and competition to fill the interminable hours of confinement and affirm their physical prowess. Many prisoners became obsessed with the male body as the symbol of German power. POWs were counselled to maintain their bodies in perfect condition for the time when the fatherland would again require them. Their national pride was fed by the image of health and strength that they were able to project to their Canadian captors. Historian George Mosse has documented the particular relation that German culture had developed with the male body by the time of the Second World War. More than those in other belligerent countries, German war monuments depicted strong, dynamic youth, often naked or partly naked. He argues that "[w]hile manliness and camaraderie had always been thought of as identical, within rightist groups the warrior concept of manliness triumphed during and after the [First World] [W]ar as a prerequisite for true comradeship." In a speech on the occasion of the Medicine Hat camp olympiad in August 1943, the Camp Spokesman articulated that construct when he declared that the large participation "was proof of their moral soundness." The Canadian intelligence officer, who observed his speech, recorded: 
That which had been recognised by all virile peoples - that only a healthy body could maintain a healthy spirit was in particular measure a law of the younger generation of National Socialist Germany. ... In conclusion the Spokesman reminded his fellow-prisoners that the true object of sports was fully realised only when it no longer appeared as an end in itself but when placed into the service of the nation.

For many German soldiers, the virile body symbolised, at the same time, their national and personal worth. ${ }^{35}$

With Germany in crisis, many captured soldiers had no tolerance for signs of weakness. While Germans in Canada were able to maintain good health and strong physiques, their less fortunate compatriots were suffering under conditions in Europe. When the Normandy prisoners arrived in 1944, both the guards and prisoners remarked on their impoverished condition. One Canadian Medical Officer observed:

Physique, was distinctly poor throughout .... One could not help comparing them with young soldiers of the same age in this Camp, one of the latter was overheard to remark 'I think I could lick the whole lot myself.' The general impression seems to be that if this is the stamp of men we are up against, victory is not far away.

It was exactly such inferences that the long-term German prisoners feared. For their part, many of the Normandy prisoners were not at all interested in whether the Canadians saw them as physically imposing. One praised the food and "stated that he had been through a bad time and was glad the war was over in so far as he was concerned." Such men became the targets of violence from the long-term, idealistic prisoners who saw in them an unwelcome reflection of the fate of Nazi Germany. ${ }^{36}$

The secret service police watched vigilantly for signs that relationships might be more romantic than comradely. Prisoners needed to affirm that not only the body, but the interest in it, was healthy. Having served through the great winter retreat on the Russian front, Ali $\mathrm{L}$ was pessimistic about Germany's military future when he was taken prisoner in North Africa. Arriving in Alberta in May 1943, he found that many prisoners "couldn't bear to hear the whole truth because of their National-Socialistic fanaticism," and soon learned to share his candid opinions with only trustworthy friends. At the Lethbridge camp, he became especially close to Herbert N. The Hut leader commissioned various NCOs to keep them under observation. One spy, a man from Ali's hometown, warned him to break off relations with Herbert, as the 
relationship was suspected of being homosexual. In response, Ali and Herbert went to the Camp Spokesman and asked for an official enquiry. Although evidence was tabled that they had been seen kissing and touching each other's genitals, the Spokesman cleared them of the charge in writing. Since homosexuality was such a serious accusation, taking an offensive position against the charge could be an effective tactic. To falsely accuse a prisoner of homosexuality was itself a serious breach of male social norms. ${ }^{37}$

Relationships, whether sexual or not, could become especially important and intense in the prison camp environment. Max had become increasingly depressed in prison camp since his capture in North Africa in 1941. In the Lethbridge camp in May of 1943, he developed a close relationship with a medical orderly who inspired him to enrol in courses and who lifted his spirits. Together they were transferred to Medicine Hat. When the relationship "broke because of a quarrel" in January 1944, Max unsuccessfully attempted suicide. Then, complaining of recurrent headaches, he was given luminol tablets which he saved until he had enough to kill himself. The Canadian camp psychiatrist wrote that "on the evening of the $18^{\text {th }}$ of February 1944 he had a last conyersation with his former friend" and took the pills. The orderly became suspicious and reported to a German medical officer who took him to the camp military hospital where his stomach was pumped. He remained in the hospital for two months. ${ }^{38}$

With populations of approximately 10000 POWs each, the large camps offered a pool of men to draw on for sexual, romantic or loving relationships. However, making contacts was always risky. A potential lover could reveal himself as a 'stool pigeon' at the service of the security service. One POW described the tactics of the secret service to the Canadian authorities during the war. He said that a POW sleeping on the top bunk

... asked the lower berth if he could come and visit him one night. The lower answered, no, not tonight but tomorrow night. The next morning, however, he (the lower) went to [the security service who arranged] to have him (the lower) meet the upper at a certain time and place (I believe it was somewhere in the open in the dark).... When they met, he (the lower) let himself be played a bit but when the upper started to get more aggressive 'they' came out of the dark, gave him a severe beating and dragged him to the heating room where already a typewriter had been placed where a statement was taken.

Relationships could develop from non-sexual to sexual over the course of internment. However, introducing a sexual element into a long-term friendship 
could be equally delicate. Kruger and Wilhems had both served in Regiment 361 in North Africa and had spent years together in internment. Kruger recounted to an intelligence officer that Wilhems

... came always to my room; one day he came again and tickled me and patted me on the shoulder, a behaviour which formerly he had not shown and which behaviour I thought very peculiar especially with my roommates present. I asked him if he was homosexually inclined. He got pale in his face but nevertheless we played the usual game of chess together.

Kruger implicitly managed to assert his own heterosexuality in this anecdote (or the actual situation, if his account is accurate). His response is worldly. The homosexual desire of his friend seems not to threaten him as they continue their game of chess. But Wilhems' discomfort suggests that he immediately understood that he had stepped into danger. He may have been more cautious in his future relationships. On the other hand, Kruger also seems to imply that, without his roommates present, moves were not necessarily confined to the chessboard. ${ }^{39}$

Finding a safe place was essential and prisoners were imaginative and alert to the possibilities. One ex-POW remembered walking his dog on a foggy morning at Medicine Hat and coming across two prisoners kissing. Aware of his presence, they disappeared into the protection of the fog. The observer remembered it as a romantic moment. The following letter, confiscated from a prisoner still at the Petawawa camp to his friend who had been temporarily transferred to a work project in South River, Ontario, keeps the latter up to date on camp gossip:

Here in your former hut, things have changed, but at least nobody belonged to the KDP [Communist Party]. Ermel and his sweetheart have apparently been transferred to another camp. Bubi and his darling are sitting as always for hours on a bench and gaze each other silently in the eyes. Often they play table tennis and the trouble is that the ball gets lost. Naturally it can only be found under the stage where the two of them immediately went to look for it but could not find it right away ....

This note suggests that, in the daily life of the prison camps, the sexual choices of comrades were regularly subject to gossip. ${ }^{40}$

The intensity of the anti-homosexual campaign increased after the attempt on Hitler's life on 20 July 1944, (which coincided with the introduction of the 
Normandy prisoners to the camps). In response, Hitler directed that it was the duty of all Germans to find and execute enemies of the Reich. Those orders were received from Germany via short-wave radios concealed in camps. This motivated the Hitlerites in Canada to increase their assault on the Reich's enemies. Throughout the summer of 1944, rigorous investigations at the Medicine Hat camp unearthed several homosexual networks. The secret service targeted NCOs who were unpopular within their ranks or pessimistic about the future of Nazi Germany. For instance, Hermann $\mathrm{K}$ had increasingly alienated himself from his comrades by giving voice to the likelihood of an Allied victory. He felt that they "were looking for a reason to beat" him up. Hermann confided his homosexual adventures to a prisoner who was working as a mole for the secret service. He was betrayed and called to trial at a "Court of Honour" on 4 August 1944. The Camp Spokesman and other officials found him guilty of having had sexual relations with seven prisoners, all of other ranks. Although he admitted that he had been involved in homosexual relations, he argued that it was unjust that "similar cases had been suppressed and I should be accused." Another court on the same date listened to evidence in the case of Emil, also an NCO. $\mathrm{He}$ too was found guilty of having sexual relations with men of other ranks. ${ }^{41}$

The following day, representatives from each hut were paraded to the recreation hall for a 'degrading ceremony.' With approximately 800 prisoners present, Hermann and Emil were stripped of their shoulder braids and stars While to be labelled 'homosexual' was a profound disgrace, it seems to have been reserved primarily for those who had insulted German pride. After the ceremony, as the crowd filed out of the hall, Hermann noticed four notorious henchmen waiting for him. When they told him to follow them, he appealed to the Spokesman for protection, arguing that "I would have to face the authorities in Germany and that I had no intention to let myself be killed by his henchmen." The Spokesman replied that he "should have contemplated these things before." Led back to his hut, he was beaten with sticks, ropes and fists:

The whole twelve men fell over me or beat me up at the same time. As I was not able to rise from the floor I tried to crawl away and this opportunity Kochendoerfer used in stepping on me. Then I tried to crawl under the bed in order to protect myself. Kockendoerfer [sic] sat on me again and I did not succeed in getting under the bed ... the hut leader O/Fwb. Schulte arrived on the scene and shouted 'Stop it, it is no use.' When they did not stop they kept on hitting me and Thomsen said 'He isn't dead yet.' The hut leader then again shouted 'Stop it' and gradually they ceased beating me one after the other. 
He was taken to the enclosure hospital where he remained in bed for six days. The German doctors who ran the hospital refused to treat him. This was the normal procedure for victims of anti-homosexual aggression; not surprising given the ranking medical officer was also in charge of approving the beatings. In fact, another POW reported that when he was admitted the following week after an equally severe beating, the German Medical Officer "looked at me and said it was a marvellous piece of work," but offered no medical attention. They were considered "unofficial" patients, which meant that the Canadians were not made aware of their injuries. ${ }^{42}$

Hermann was able to walk by 20 August, fifteen days after the beating. As soon as he was able, he presented himself to the Canadians and asked to be taken into protective custody. Canadian military doctors advised that his injuries were substantial enough to cause permanent disability. While a Canadian court of enquiry brought his comradely admonition into the military record, economic considerations drove the search for justice. Major-General Walford, Adjutant-General, in reviewing the courts of enquiry relating to three such cases noted that

the cost to the Crown for the hospitalisation and treatment [of three POWs] so far amounts to $\$ 359.00$, in view of which the reviewing authority has requested further information in regard to ... what efforts are being made to avoid such occurrences ... [and] what action has or can be taken by the Commandants ... against the Camp Leaders, Section Leaders and Hut Leaders under whose control and protection the PW are when such injuries are suffered.

Walford ordered that POWs be charged before the Camp Commandant for the offence of "committing physical violence against any other Prisoner of War." 43

Thus, the Canadian military once again came to the protection of German homosexuals. The intelligence officer at Medicine Hat had a clear statement from Hermann who was able to name five of his twelve assailants. But finding corroborating evidence from other prisoners was difficult. Eight hundred prisoners had witnessed Hermann's degrading. Fearful for their own security, none came forward. The German doctors and authorities denied all knowledge. However, two German orderlies agreed to testify that Hermann had been in the enclosure hospital. Under Canadian military law, summary statements were taken in the presence of the accused, who had the privilege of questioning witnesses. Ominously, the two orderlies were asked by the aggressors one simple question: "Are you still in the enclosure?" There is no record of their subsequent fate in the enclosure.

At their courts martial, the five accused were defended by a civilian 
lawyer. He conceded that Hermann had been beaten as a "homosexualist" and argued that he was motivated by bitterness and revenge in pretending to be able to identify his attackers. He argued that Hermann's vindictive personality was the result of his "perverted mind." Given the severity of the beating he received, Counsel argued that Hermann could not have been cogent enough to take notice of who was administering it. Predictably, he tried to discredit Hermann by dwelling upon his homosexual activities. Hermann's candid responses were rare for the period and they opened him up to an attack on his character. Counsel based his defence on the assumption that in the eyes of the court, Hermann would be seen as guilty of the greater crime of homosexuality. The court, however, had clear evidence of the beating from Canadian and German sources and it accepted Hermann's account of who had performed it. ${ }^{44}$

A month after Hermann's comradely admonition, another POW was murdered at Medicine Hat. As a result, intelligence officers were confronted with hundreds of men asking to be taken into protective custody. In each case, they interviewed the prisoner to determine the basis for his claim for protection. Joshua was an intelligence officer at the Medicine Hat camp who interviewed prisoners asking for protection. Five decades later, he reflected on the contradiction of the Canadian military protecting German homosexuals while it prosecuted its own queer servicemen:

The homosexuals in the Army were being disciplined because it was against regulations, it was considered not right. The ones in the camp - prisoners of war - you were responsible for them staying alive. The ones outside, you could discharge them - get rid of them.

Q: You can't discharge a prisoner. Why not repatriate them? A: ... I doubt they would do it on that ground. The only thing you could do was take them out and put them into protective custody in the camp, which is what they did.

Called the "westlines" at the Medicine Hat camp, this community of anti-Nazis and homosexual Germans lived outside the barbed wire, but immediately adjacent to it. Employed by industries in Medicine Hat, they went into town daily. Many also celebrated their new freedom by forays into the town in the evenings. For those still on the inside, the spectre of their traitors enjoying the freedom they were denied was infuriating. ${ }^{45}$

Asking to be taken into protective custody was an option available to all prisoners under the Geneva Convention. For those like Hermann, whose lives were threatened inside the enclosure, it was necessary for survival. But Hermann's case is representative of the desperate conditions that prisoners would accept before seeking protective custody. It entailed placing oneself in 
the arms of the enemy during a time of war. It meant breaking ties with one's homeland: family, friends and culture. Most shared no language with the Canadians, were in a foreign land far from their homes and had no idea of how they would be treated by the enemy. They were warned that there would be reprisals against their families in Germany. There were also very persuasive means employed by the prisoners to make seeking protective custody a risky operation. One prisoner in protective custody named Werner described to an RCMP officer a camp meeting at Medicine Hat in September of 1944. The Spokesman had proclaimed that

to keep order and discipline in the camp, ... we should not have secret gatherings or clubs, we should not talk to the Canadians, or listen to outside information, or pass out any information from the camp, watch each other for traitors within the camp. ... [L]ater there was general talk in our room that the camp leaders lecture was right and that we should watch each other for traitors.

But Werner had a lover in the camp and was vulnerable. Soon after that meeting, he slit his throat in an attempted suicide. When he recovered, he and his lover decided to take their chances with the Canadians. ${ }^{46}$

For homosexual prisoners who had achieved a measure of status in German society, asking the Canadians for protective custody could be especially difficult. Hermann had suffered much persecution and a public degrading before he chose to sever his ties with his German comrades. As an act of defiance, once outside the enclosure, he sewed his epaulettes back onto his uniform, reclaiming his status as an NCO notwithstanding his homosexuality which he publicly acknowledged. In the Lethbridge camp, Doctor X was a respected physician working in the camp hospital. His German colleagues rated his professional ability highly. As a medical officer, he was privileged to have his own quarters in the hospital, which allowed him a rare measure of privacy. Investigations found that he was carrying on sexual relations with at least eight prisoners, three of whom worked as orderlies in the camp hospital. Doctor X was not subjected to the comradely admonition that would have confronted other ranks or NCOs in the same position, but was removed from his work as doctor. He then took an overdose of drugs and slit his wrists in a nearly successful suicide attempt. At this point, the Canadian authorities were made aware of the problem. Doctor $X$ asked to be sent to another camp, where his homosexual past would be unknown and where he could continue his medical work. Both Canadian and German authorities saw this as impossible, however, and it was proposed that he be sent to the officer camp at Gravenhurst for the duration of the war. ${ }^{47}$ 
Canadian military intelligence (MI7) became responsible for segregating the prisoners into separate camps according to six political shadings, from black (Nazi) to white (democratic). Intelligence officers interrogated and graded each prisoner. In the course of the interrogations, intelligence officers sometimes established contacts who described details of camp society. For instance, the intelligence officer at the Farnham camp in Quebec reported to his superiors that Major Hans Spinner's homosexuality was "confirmed by [the] most reliable sources inside." The official history of the Directorate of Military Intelligence (DMI) describes how such information could be used by the Canadian Army. Knowing that POWs were using a secret ink for communications between camps, but unsure of how, DMI decided to plant a mole. The official historian of Canadian Military Intelligence recounts that the Deputy Director of Military Intelligence (Security)

knew that the senior German general most likely to be in charge of $A b w e h r$ [German military intelligence] operations in Canada had bizarre sexual inclinations, so an effort was made to find a person who might appeal to him. The volunteer was a young Romanian who hated the Nazis ... he was thoroughly schooled to meet all eventualities and, in due course, was moved to the General's camp. His face was beaten, with his approval, to show that his Canadian captors did not approve of his inclinations. He succeeded in his mission, but during the last stage the Camp Gestapo became suspicious. He was 'executed' by hanging, arranged by the Gestapo, as usual, to suggest a suicide. As pre-planned, he had inserted the evidence in his body, to be reclaimed at the autopsy. ... He was a valiant man.

This account was purportedly based on evidence from the officers commanding DMI during the war. It is possible that the author, Major Elliot, was attempting to charm a 1970s Canadian military audience with the story: the Nazi is presented as a sexual pervert and the Canadians attempt to outwit him by physically beating the 'homosexual' mole. Although Major Elliot offers no other details, he seems to suggest that beating the mole was a way of signalling to the Germans that he was homosexual. Presumably, the Canadian intelligence officers believed that by advertising his homosexuality in that way, the German General would identify him as a potential sexual partner and befriend him. As we have seen, the Canadian Army was actually protecting German homosexuals throughout the war from Nazi persecution within. (Perhaps Major Elliot is aggressively distancing the Canadian Army from that fact.) If Major Elliot's account is accurate, the Canadians' strategy was foolhardy. The POWs were 
well aware that Canadians were exploiting the situation that alienated homosexual Germans and forced them to the Canadian side of the wire. Beating the Romanian for being homosexual would have triggered the suspicions of the German officers and made him vulnerable inside the enclosure. Moreover, how would the Canadians have known that he would be attractive to the German General? The evidence as presented suggests that Canadian military intelligence had learned very little from all that was available to it. This is consistent with the documentary evidence: although many individual interrogations and courts martial discuss the brutal treatment of homosexuals, never do the hundreds of intelligence reports broach the issue. ${ }^{48}$

Other ranks who felt threatened by the politics of the enclosure had a crucial advantage over officers in the same position. The Geneva Convention provided for their employment in industries not directly related to the war effort. In Canada, the lumber industry exploited the availability of a captive labour force. Dozens of camps, each of between fifty and one hundred prisoners, were spread primarily across northern Ontario from the fall of 1943 until the prisoners were repatriated in 1946. In these camps, many soldiers found an escape not from Canadian confinement, but from the oppression of their comrades. As a long-term prisoner, Bob Schumacher had priority in transferring to a lumber project where he escaped "the super duper idealists" in the Lethbridge POW Camp. Bob recalls, "In the bushcamp, I felt very good. But the big camps were no good, you see." For Hermann Hutt, blacklisted by the NCO elite in Medicine Hat, the options were to seek protective custody or to go to a bush camp. The bush camp allowed prisoners like Bob and Hermann the opportunity to escape Nazi control without renouncing Germany or placing themselves in the arms of the enemy. ${ }^{49}$

Bob remembers a prisoner, employed in the laundry at his lumber camp at Long Lac, Ontario, who "had a female face and a female walk." A homosexual subculture developed around him: "that clique was five guys in the camp, they celebrate down there almost every day. ... [T]hey was queers." The four others worked as lumberjacks during the day and spent their social time together. "Everybody know but nobody said anything." Entrapment would have been easy, Bob speculates, if anyone had been interested: "All I have to say I was drunk too. All I have to do is do like I was willing to do it." However, in the shadow of Medicine Hat and Lethbridge, the Long Lac lumberjacks lived with a degree of mutual respect. Bob's speculation also provides an insight into how those who were unwilling to identify too closely with the queer element of the camp might nevertheless participate in it. With an abundance of home-made blueberry liquor available to the POWs, anyone could induce a temporary suspension of accountability. ${ }^{50}$

The end of the war brought a new relationship between the POWs and the Canadian military authorities. The Nazi Party no longer controlled camp poli- 
tics and the intense nationalism that had tried to eradicate the 'weak' elements from the German community subsided. There is evidence that at some camps, POWs began to turn homosexual cases over to the Canadians for punishment. At the Monteith camp, which contained naval personnel and the enemy merchant seamen formerly of the Ripples camp, Gustave and Paul received 28 days detention from the Commandant on a charge of "did indulge in homosexual practices" as early as August of 1944. (Recall that according to the report of the Committee into Homosexual Practices at the Ripples camp in January 1943, the enemy merchant seamen had agreed to hand subsequent homosexual offenders over to the Canadian authorities for punishment.) At Lethbridge, in October 1945, Hans-Juergen was observed by three German NCOs having sex with another lance corporal. He too was summarily sentenced by the Commandant to 28 days detention for "an act of bestiality, having been caught ... engaged in an act of sodomy with [another POW, Justus]." 51

The Canadian Army handed the investigation of the murders of two POWs, August Plaszek and Karl Lehmann, to the RCMP. Detectives generated huge files over nearly three years (1943-1946) as they listened to gossip, followed leads and tracked down prisoners who were frequently transferred to new camps or labour projects. DPOW and DMI forwarded interrogation reports that often provided insights into camp politics. In this way, the RCMP came to amass much information on the regulation of homosexuality, relying primarily upon information supplied by those who escaped the enclosure and accepted Canadian protection. Evidence was gathered that both of the murdered men had been involved in homosexual subcultures. Homosexuals who had been targeted by the prisoners' secret service found themselves in positions to avenge the murders of their friends and their own mistreatment. For instance, the RCMP knew that a POW named Adolf "had sought protection owing to his having been accused as a homosexualist." Before he fell from grace with the secret service, Adolf had been "very friendly" with one of the murderers and was able to provide the detectives with information that led to the arrest of all those responsible for the murder of Karl Lehmann. The RCMP, in co-operation with the POWs in protective custody, sometimes turned the tables on suspects, taking them out of the enclosure and leaving them in confinement with those they had previously terrorised. The former victims were not above using the tactics of intimidation learned from their persecutors. In this way, the RCMP profited from the help of homosexual POWs, none of whom were charged under the Canadian criminal code, even in cases where they admitted their transgressions. The homosexual prisoners were not security risks to the Nazis because of their sexuality, but because of the mistreatment they had suffered and the crimes committed against themselves and their friends..$^{52}$

Seven German prisoners were prosecuted for the murders of August Plaszek and Karl Lehmann in Canadian criminal court. Eventually, five would 
be found guilty and executed. In each case, the strategy for the defence centred on the homosexual subculture in the camps. Defence lawyers, like the counsel for the aggressors at the Ripples camp, argued that the Canadian Army had abrogated its responsibility by not prosecuting homosexual crimes within the enclosure. The prisoners were therefore justified in prosecuting all crimes, including treason, under German law. This strategy had the effect of hanging the prisoners' dirty laundry out to dry in the Canadian courts. After years of trying to hide their homosexual comrades from Canadian view, it was now in their personal interest to expose them. However, some prisoners regained the high ground by charging the Canadians in open court with moral laxity. Commenting on the fact that the prisoners who had beaten queers were prosecuted while the homosexuals were not, Max Voigt remarked in court that he assumed "that homosexual offenders are permitted in Canada." This provoked the following admonition from Chief Justice Howson:

Before you leave this country I want to tell you that I do not propose that you will stand up here in a Canadian Court and insult the Canadian people or the Canadian authorities, and if that is your German mind, you had better change it ... I have heard all I want to from you; you can go.

In fact, bench, defence, prosecution and witnesses competed with each other over who was the most intolerant of homosexual vice. ${ }^{53}$

The prosecution answered the defence strategy by citing Article 45 of the Geneva convention: "prisoners shall be subject to the laws, regulations and orders in force in the armed forces of the detaining power." While this seemed just to the jurors, one wonders if they would have been as sympathetic to this clause if they had considered that it also applied to Canadian POWs in Germany. In fact, during the trials, the probability that Canadian POWs were equally defiant of the enemy motivated the JAG office to issue a memorandum declaring any such courts ultra vires and invalid. It found that indeed Canadian POWs had held similar courts in enemy hands. ${ }^{54}$

\section{Conclusion}

Jewish refugees, civilians and enemy merchant seamen, and German combatant prisoners were interned in Canada in all-male camps throughout the Second World War. Homosexual relations frequently developed among the inmates. However, the mix of internees in individual camps and the circumstances of their internment determined the significance of those relations. Long before any inmate was imprisoned, physical and romantic intimacies between men had been cast as immoral, degenerate and unmanly. Any person or group that 
wanted to consolidate political power within the camp enclosures could appeal to the need to protect decent men from corruption. In the most virulent antihomosexual campaigns, POWs marked as queer by the prisoner administration were beaten and sometimes killed. The fortunate ones managed to escape dangerous environments and pass the war in the relative safety and health of smaller work camps.

The Canadian state accumulated much information about the political uses of homosexuality as a result of its intelligence activities and criminal investigations into assaults, murders and riots. The Army, RCMP and criminal justice system were presented with much evidence relating to the influence of sexual politics on prisoner society in the Class Two and Class Three camps. The material that filled their files showed that homosexual prisoners among the German armed forces were highly reluctant to betray their compatriots. Even those who rejected Hitler and National Socialism felt themselves to be part of a larger German community. They preferred the lives to which they had accustomed themselves over the years than to the unknown of Canadian protection. Nevertheless, when faced with the choice between violence or death at the hands of Nazi henchmen or protective custody with the Canadian Army, they often chose the latter.

In both German and Canadian culture, to be a good man and an upright citizen meant to renounce sexual perversion and to demonstrate an intolerance for the weakness of one's comrades, whose depravity weakened the community. But all homosexuals were not equal; the perversions of those with solid credentials or those whose rank placed them out of reach were often overlooked. For the Canadian military who oversaw the POWs, homosexuality was a way to exploit the tensions that divided the enemy. However, Canadian military intelligence remained naïve concerning the dynamics of prisoner sexual politics despite collecting much evidence about the details of life in the enclosure. Presented with the knowledge that a high-ranking German General was homosexual, it is notable from a historical perspective that the Canadians did not consider blackmail, but proceeded in the same way that they might with a heterosexual enemy with intelligence to offer: they planted a sexually attractive mole to seduce him and discover his information. The RCMP also learned that homosexual enemies remained loyal to their compatriots until, in despair for their lives, they sought protection from their Canadian captors. Thus, homosexuality developed as a significant factor within internment operations, offering pleasure to some, a route to power for others and distress to a great many of their victims. In response, the Canadian Army accepted that there was little hope in finding or prosecuting the many homosexual violations that seemed to be inherent in the all-male environments. As a result, it contented itself with prosecuting those who disturbed the peace by persecuting their queer comrades and handed out minor terms of detention when cases of homosexuality came to 
light. In part, it was implicitly describing the conditions which also governed queer Canadian servicemen in Canadian units. However, Canadians were punished much more severely for their sexual transgressions than the Germans under Canadian control. And while those Canadians who exposed their queer comrades were not always appreciated at the personal level, they were supported institutionally.

\section{Notes}

${ }^{1}$ Erik Jensen, "The Pink Triangle and Political Consciousness: Gays, Lesbians, and the Memory of Nazi Persecution," Journal of the History of Sexuality 11, 1/2 (January/April 2002): 319-349; Jesse Green, "When Political Art Mattered," New York Times December 7, 2003, 69; Gunter Grau, "Final Solution of the Homosexual Question?: The Antihomosexual Policies of the Nazis and the Social Consequences for Homosexual Men," in The Holocaust and History: The Known, the Unknown, the Disputed and the Reexamined, ed. Michael Berenbaum and Abraham J. Peck (Bloomington and Indianapolis: Indiana University Press, 1998); Elizabeth Heinman summarises the literature dedicated to painting Nazis as homosexual in "Sexuality and Nazism: The Doubly Unspeakable?," Journal of the History of Sexuality 11, 1/2 (January/April 2002): 22-66; Lothar Machtan tries to call Hitler gay in The Hidden Hitler (New York: Basic Books, 2001); Manfred Herzer looks at the contemporary mudslinging in "Communists, Social Democrats, and the Homosexual Movement in the Weimar Republic," in Gay Men and the Sexual History of the Political Left, ed. Gert Hekma, Harry Oosterhuis and James D. Steakley (Birmingham: Harrington Park Press, 1995).

2 Enemies Within: Italian and Other Internees in Canada and Abroad, ed. Franca Iacovetta, Roberto Perin and Angelo Principe (Toronto: University of Toronto Press, 2000), especially Luigi Bruti Liberati, "The Internment of Italian Canadians"; for an analysis of the Italian Canadian redress campaign, see Franca Iacovetta and Robert Ventresca, "Redress, Collective Memory and the Politics of History," in the same collection.

${ }^{3}$ Paula J. Draper, "The 'Camp Boys': Interned Refugees from Nazis," in Enemies Within, 85; Chris Madsen and Bob Henderson, German Prisoners of War and their Artifacts 1940-1948,73, note that "active gays often faced the full wrath of an enraged prisoner population" but the authors give no footnotes or details.

${ }^{4}$ Richard Plant, The Pink Triangle: The Nazi War Against Homosexuals (New York: Holt and Company, 1986); Gunter Grau, Hidden Holocaust: Gay and Lesbian Persecution in Germany 1933-1945 (London: Cassell, 1995); Geoffrey J. Giles describes various dimensions to the Third Reich's opposition to homosexuality in, "The Institutionalization of Homosexual Panic in the Third Reich," in Social Outsiders in Nazi Germany, ed. Robert Gellately and Nathan Stoltzfus (Princeton and Oxford: Princeton University Press, 2001); on the complex relationship between National Socialism and Röhm, see Eleanor Hancock, "Only the Real, the True, the Masculine Held Its Value': Ernst Röhm, Masculinity, and Male Homosexuality," Journal of the History of Sexuality 8, 4 (1998): 616-641. 
5 Giles, "The Institutionalization of Homosexual Panic in the Third Reich," 235.

${ }^{6}$ On the constructions of homosexuals as seducers of youth and enemies of the state, see ibid.; Rudiger Lautmann, "The Pink Triangle: Homosexuals as 'Enemies of the State'," in The Holocaust and History: The Known, the Unknown, the Disputed, and the Reexamined, ed. Michael Berenbaum and Abraham J. Peck (Indianapolis: Indiana University Press, 1998.)

${ }^{7}$ Paul Jackson, One of the Boys: Homosexuality in the Military during the Second World War (Montreal and Kingston: McGill-Queen's University Press, 2004); Gary Kinsman, "Constructing Gay Men and Lesbians as National Security Risks, 1950-1970," in Whose National Security?: Canadian State Surveillance and the Creation of Enemies, ed. Gary Kinsman, D. Buse and M. Steedman (Toronto: Between the Lines Press, 2000). ${ }^{8}$ Bob Moore, "Axis Prisoners in Britain during the Second World War: A Comparative Study," in Prisoners of War and their Captors in World War II, ed. Bob Moore and Kent Fedorowich (Washington: Berg, 1996); Eric Koch, Deemed Suspect: A Wartime Blunder (Toronto: Methuen, 1980), xiv, 246.

${ }^{9}$ For the most developed analyses regarding civilian internees, see Enemies Within. Earlier studies include Robert Keyserlingk, "Breaking the Nazi Plot: Canadian Government Attitudes Towards German-Canadians, 1939-1945," and Bruno Ramirez, "Ethnicity on Trial: The Italians of Montreal and the Second World War," in On Guard For Thee: War, Ethnicity and the Canadian State, 1939-1945, ed. Norman Hillmer, Bohdan Kordan and Lubomyr Luciuk (Ottawa: Canadian Committee for the History of the Second World War, 1988); Robert Keyserlingk, "“Agents Within the Gates': The Search for Nazi Subversives in Canada during World War II," Canadian Historical Review 66, 2 (1985): 211-239. The internment of communist sympathisers is documented by Reg Whitaker, "Official Repression of Communism During World War II," Labour/Le Travail 17 (Spring 1986): 135-166; Kathleen and William Repka, Dangerous Patriots: Canada's Unknown Prisoners of War (Vancouver: New Star, 1982). The Canadian fascists who came to be interned are studied by Lita-Rose Betcherman, The Swastika and the Maple Leaf: Fascist Movements in Canada in the Thirties (Toronto: Fitzhenry and Whiteside, 1975) and Jonathan Wagner, Brothers Beyond the Sea: National Socialism in Canada (Waterloo: Willard Laura University Press, 1981).

${ }^{10}$ Madsen and Henderson, German Prisoners of War, 5-6.

11 Directorate of History and Heritage (DHH), file 113.3P4 (D1), Colonel Streight, "Preliminary Historical Narrative of the Directorate, Prisoners of War."; DHH, file 158.D13(D1), "Historical Section (G.S.) Army Headquarters, The Veteran's Guard of Canada.."; DHH, File 78/525, "Regulations Governing the Maintenance of Discipline Among and Treatment of Prisoners of War."; DHH, file 322.009 C058 for an account of the Nazi organisation at the Lethbridge camp. Internal organisation varied among the camps and only some were uncovered and recorded. The Medicine Hat camp is welldocumented as a result of RCMP investigations. See Medicine Hat Museum and Art Gallery Archives (MHMAGA), file m90.3.11 Brief re: P/W no. 19769 Karl Lehmann murder of; NAC, RG 24, reel C-5415, file 7236-94-2, vol. 2, "The Disciplinary Authority of Camp Leaders in Other Ranks Camps" (English translation); NAC, RG 13, Volume1658 $(1.1,1.2,2)$ c.c. 607,281 describes how punishments were enforced at the Medicine Hat camp. Some of the henchmen assigned to administer punishment are listed in MHMAGA, m90.3.6, 1945/06/12. Reference to the Nazi control of the camp inte- 
rior of the Kananaskis Camp, shared by civilian internees and communists early in the war, is made in Ian Radforth, "Political Prisoners: The Communist Internees," in Enemies Within, 212.

${ }^{12}$ Koch, Deemed Suspect, 157-8.

${ }^{13}$ Homosexuals were similarly excluded from power structures in concentration camp society in Germany - see Lautmann, "The Pink Triangle: Homosexuals as 'Enemies of the State', 353; Heinz Heger, The Men with the Pink Triangle (Boston: Alyson Publications, 1980); Eugen Kogon, The Theory and Practice of Hell: German Concentration Camps and the System Behind Them (London: Secker and Warburg, 1950), 34 .

${ }^{14}$ Two separate publications mention the incident at Ripples. Neither account mentions homosexuality and both are vague concerning the cause of the disturbance: Mario Duliani, La ville sans femme (Montreal: Société des éditions Pascal, 1945) and Jones, Both Sides of the Wire, vol. 2.

${ }^{15}$ For camp conditions, see Jones, Both Sides of the Wire.

${ }^{16} \mathrm{DHH}$, file 167.009 (D110).

${ }^{17}$ RG 24, reel C-5397, file 7236-80-70, "Confidential Report," 1943/01/30 Spokesman Brendel to Commandant Bedson.

${ }^{18} \mathrm{DHH}$, file 167.009 (D110). The practice of atomising the population by setting individuals against each other was fundamental to the Nazi exercise of power. Denunciation of one's neighbours was widespread under the Nazi system - see Robert Gellately, The Gestapo and German Society: Enforcing Racial Policy, 1933-1945 (Oxford: Clarendon Press, 1990) and Stefan Micheler, "Homophobic Propaganda and the Denunciation of Same-Sex-Desiring Men under National Socialism," Journal of the History of Sexuality 11, 1/2 (January/April 2002): 95-130.

${ }^{19} \mathrm{DHH}$, file 167.009 (D110).

${ }^{20}$ Ibid.

${ }^{21}$ Ibid., 1943/07/15, RCMP report.

${ }^{22}$ Confinement meant that it was easier to follow Himmler's instructions for the pursuit of homosexuals in Canada than in Germany: Giles, "The Institutionalization of Homosexual Panic in the Third Reich," 243.

${ }^{23}$ DHH, file 167.009 (D110); NAC, MG 30, C 199, reel 7495, Oskar Demuth, 18841974, World War II internee, discusses his disappointment that those guilty of indecency had all been German.

${ }^{24}$ RG 24, reel C-5397, file 7236-80-70, 1943/02/09, court of enquiry. The focus on the 'seducers' reflects the thrust of Nazi policy: Giles, "The Institutionalization of the Homosexual Panic in the Third Reich," 243.

${ }^{25}$ RG 24, reel C-5413, file 7236-91-4-70; DHH File 167.009 (D110).

${ }^{26}$ The DND similarly requested that provincial coroner's inquests into the deaths of POWs working on labour projects be investigated by military courts of enquiry instead, which could remain closed and hidden from German view. NAC, RG 24, reel C-5407, file HQS 7236-85-10 contains correspondence between the Army and provincial attorneys-general regarding the request.

${ }^{27}$ NAC, RG 24, reel C-5397, file HQS 7236-80-70, Brig Angin to Sec, DND, 1943/02/12. Trials: RG 24, reel T-15655, file HQC 55-K-193; reel T-15664, file HQC 55-L-507; reel T-15664, file HQC 55-L-508; reel T-15685, file HQC 55-M-832; reel T- 
15685, file HQC 55-M-831; reel T-15730, file HQC 55-R-328; reel T-15730, file HQC 55-R-327; reel T-15742, file HQC 55-S-570; reel T-15742, file HQC 55-S-569; reel T15773, file $55-\mathrm{W}-360$.

${ }^{28}$ This is a composite of the argument presented in the ten separate trials. Its form depended on the particulars of the case. For instance, some defendants were enemy merchant seamen, others civilian internees. Arguments also varied with the age and position of the accused. NAC, RG 24, reel T-15730, 55-R-327, folio 71, 72; reel T-15773, 55-W360, folio 371, 373; reel T-15742, 55-S-569, "L"; reel T-15730, 55-R-327, folio 71, 72; reel T-15664, 55-L-508, folio 129; reel T-15773, 55-W-360, folio 371, 373; reel C-5420, file 7236-95-1-70, Colonel Streight to DAG, 1943/06/26.

${ }^{29}$ NAC, RG 24, reel C-5397, HQS 7236-80-70, Lyon's report, 1943/07/15.

${ }^{30}$ For monthly intelligence reports for various camps, see NAC, RG 24, reel C-5407, reel C-5415, reel C-5416, reel C-8249, reel C-8250; DMI intelligence reports DHH 322.009; POW personnel files (restricted): RG 24, reel C-8437. Camp politics and conditions are discussed in extensive RCMP reports relating to the investigation into the murders of POWs: Glenbow Archives M2124, file folder 3; MHMAGA M.90.3.

${ }^{31}$ For instance, all of the four convicted of the murder of Lehmann were amongst the first to arrive in Canada. NAC, RG 13, C.I., vol. 1658, 236. (P and M); Ian Kershaw, Hitler (London: Longman, 1994), 118; Plant, The Pink Triangle; NAC, RG 24, reel C5415, file 7236-94-2, vol. 2.

${ }^{32}$ NAC, RG 13, C.I., vol. 1659, Willy Mueller, c.c. 609, 165. Riehme acknowledged that such comradely admonitions sometimes sent homosexual POWs to the hospital, but "in many cases" they were less serious.

${ }^{33}$ Interviews with ex-POWs confirm this account of their cosmopolitan reputation: Max Weidauer interview, Paul Mengelberg interview; quote from Carter, Behind Canadian Barbed Wire, 164.

${ }^{34}$ The stated motivation for his murder remained his alleged treasonous conduct. In fact, there was no evidence of such at the criminal trials of his murderers; NAC, RG 24, reel C-8437 file HQS 9139-P-794, DND(A) I.S. 100-10, Lt-Col Black, 1945/11/24; RG 13, C.I. vol. 1658 (Addie Kratz), 417-38. Kazmierzack's connection with a number of Legionnaires, and his own indictment as homosexual is suggestive; re homosexuality of Walter Wolf, see, inter alia, MHMAGA, file m.90.3.9, Corporal Krause RCMP CIB report, 1945/11/28. While the SS had the most severe punishment for homosexuality in Nazi Germany, the death penalty, it also led the way in denying the incidence of samesex sexuality within: see Geoffrey J. Giles, "The Denial of Homosexuality: Same-Sex Incidents in Himmler's SS and Police," Journal of the History of Sexuality 11, 1/2 (January/April 2002).

${ }^{35}$ George Mosse, Fallen Soldiers: Reshaping the Memory of the World Wars (New York: Oxford University Press, 1990), 169; Mosse, Nationalism and Sexuality: Middle-class Morality and Sexual norms in Modern Europe (Madison: University of Wisconsin Press, 1985); NAC, RG 24, reel C-5416, file HQS 736-94-6-132, vol. 1, intelligence report 1943/09/30.

${ }^{36}$ NAC, RG 24, reel C-8249, HQS 31-15 vol. 2, 1944/07/09, Capt. T Dunne M.O., 30 Company, VGC to Commandant, Medicine Hat.

37 Glenbow Archives, Volume M2124, file folder 3, Lethbridge 1945/06/09. Herbert described himself as "very friendly" with Ali to the RCMP and told them that Woehrlin 
and Ewert were the main instigators in the murder of POW Lehmann. In fact, they were not involved and Herbert may well have been trying - with some success - to make their lives as uncomfortable as they had made Ali's and his. See Medicine Hat Museum, file m90.3.6, RCMP report 1945/08/14.

${ }^{38}$ NAC, RG 24, reel 7052. File restricted.

${ }^{39}$ Populations varied according to many factors: the arrival of new prisoners, transfers, numbers of prisoners out on works projects. Medicine Hat and Lethbridge were built to accommodate 12000 and, at times, that number was surpassed; Glenbow Archives, Volume M2124, file folder 3, 1945/11/24, Ogefr. Schweizer, Herman intelligence report; NAC, RG 24, reel C-8437, file HQS 9139-P-794 (Plaszek, August), 1945/11/24 Intelligence Report, Lt-Col F.O. Black for Lt-Col Pinkham Comm.

${ }^{40}$ Viktor Freelandt interview; RG 24, Reel C-5416, file HQS 7236-94-6-33. Camp censors often intercepted such letters from prisoners working on works project to their comrades back at base camps. Barbara Lorenzkowski tells me that the term 'Bubi' would have been an insulting diminutive in this instance, i.e., 'his Sweetheart.'

41 Albert Speer, Inside the Third Reich (New York: The Macmillan Company, 1970), 394; NAC RG 24 reel C-8437 file HQS 9139-P-794, I.O. Paul Neavby to GSO, DOC, MD10, 1945/10/29, part II; reel T-15635, file 55-B-1706, C55; reel C-5416, vol. HQS 7236-94-6-132, vol. 1, Intelligence Report \#30, 1945/02/28.

42 NAC, RG 24, reel T-15635, file 55-B-1706, C33; C7; In the case of Medicine Hat, Doctor Nolte approved the comradely admonitions and ran the hospital. RG 13, vol. $1658(1.1,1.2,2)$ c.c. 607, 128; NAC, RG 24, reel C-5406, file HQS 7236-85-3, 1944/11/23, Lieutenant Smulders to Commandant; 1944/12/16 Brigadier Harvey to The Secretary, DND; reel T-15635, file 55-B-1706, C77.

${ }^{43}$ NAC, RG 24, reel T-15635, file 55-B-1706, C91; RG 24, reel C5406, HQS 7236-85$3,1944 / 12 / 16$, Walford to DOC MD 13; 1944/12/29, Major General Walford Circular.

44 NAC, RG 24, reel T-15635, file 55-B-1706.

${ }^{45}$ From Lehmann's murder (1944/09/10) to 1944/10/24, 120 POWs sought protective custody in the Medicine Hat camp. MHMAGA, file m90.3.10, RCMP report 1944/10/30; Joshua (pseudonym) interview, October 1998.

46 NAC, RG 24, vol. 1592 Lehmann, Karl. RCMP Report 1944/09/23, J. Stanton.

${ }^{47} \mathrm{NAC}$, RG 24, reel T-15635, file 55-B-1706, C15; NAC, RG 24, reel T-7052, file restricted.

${ }^{48}$ Madsen and Henderson, German Prisoners of War, 86. This was part of the re-education and de-Nazification of German soldiers in Allied hands - see Henry Faulk, Group Captives: The Re-education of German Prisoners in Britain 1945-1948 (London: Chatto and Windus, 1977); Re Major Spillner, see NAC, RG 24, reel C-8249, HQS 314-40; Major S.R. Elliot, Scarlet to Green: A History of Intelligence in the Canadian Army (Toronto: Canadian Intelligence and Security Association, 1981), 511; see NAC, RG 24, reels C-5416, C-5417 for intelligence reports. DMI also received copies of RCMP reports relating to murder investigations, in which the politics governing homosexuality was well documented. NAC, RG 24, reel C-8437, file HQS 9139-PW Class MI7 Policy, 1945/04/04 Minutes of a Meeting Held in DMI's Office, 2.

49 Stephanie Cepuch, "'Our Guests are Busy': The Internment and Labour of German Prisoners of War in Ontario, 1940-1946," MA thesis, Queen's University, 1992; Bob 
Schumacher interview; Hermann Hutt interview. Similar evidence was reported by Paul Megelberg, interview.

${ }^{50}$ Schumacher interview.

51 There are very few prisoner conduct sheets extant, although all prisoners had them. Prisoner personnel files were sent back to Germany after the war, with the exception of those of prisoners who had died in Canada; RG 24, reel C-5406, HQS 7236-85-3, vol. 1. Interesting to note that there are 14 punishments in a 4 month period at the Monteith camp for "did hang blankets around his bed," culminating in the homosexual offence. Many of these prisoners had been transferred from the Ripples camp. One of the orders of the Committee into Homosexual Practices had been that prisoners were forbidden to hang blankets around their beds, since it was possible thereby to avoid observation; Sir Alexander Galt Museum, Lethbridge. P19951041003.

${ }^{52}$ MHMAGA, file m90.3.10; Material from these investigations, upon which much of this paper is based, is found in NAC, RG 24, reel C-8437, HQS 9139-L-51 and HQS 9139-P-794, MHMAGA, files m.90.3.5 to m.90.3.10 and Glenbow Archives, Calgary, file M2124; MHMAGA, m.90.8.10, RCMP report 1945/11/22, 2; NAC RG 24, reel C5413, file HQS 7236-91-4-132, esp. Commandant Bull to Col Streight, 1944/01/20; Hermann explicitly confirmed the charge and told the Canadian courts whom he had had sexual relations with - NAC, RG 24, reel T-15635, HQC 55-B-1706, C49.

${ }^{53}$ Under military law, the DND had the privilege of prosecuting offences that come under its jurisdiction or deferring to the Canadian justice department. In this case, it chose the latter option. NAC, RG 13, vol. $1657(1.1,1.2,2)$ c.c. 601 ; vol. $1658(1,2,3)$ c.c. 606 ; vol. $1658(1.1,1.2,2)$ c.c. 607 ; vol. $1658(1,2,3)$ c.c. 608 ; vol. 1659 , $(1,2,3)$ c.c. $609,165$.

54 NAC, RG 13, vol. 1659, (1,2,3) c.c. 609 , Willy Mueller, 188 ; NAC, RG 24, reel C5339, 1946/06/17 Brigadier R. J. Orde, JAG Memorandum; 1946/10/15 Colonel Laurier, Director of Records to Director of Administration lists seven known courts to have taken place among Canadian soldiers in Japanese POW camps. Arthur A. Durand, in Stalag Luft III, on page 219 cites Spivey who says that, although he had assigned investigators to check for homosexual offences among American prisoners in Stalag Luft III, he found none. 